\title{
温湿度を用いた冬期の小学校におけるインフルエンザ発生に関する時系列分析
} 学校におけるインフルエンザ発生と室内空気環境の関係に関する研究

\section{TIME SERIES ANALYSIS ON THE INCIDENCE OF INFLUENZA IN ELEMENTARY SCHOOLS DURING WINTER SEASON USING TEMPERATURE AND HUMIDITY}

Study on the relationship between indoor air environment and the incidence of influenza in schools

$$
\text { 岩下剛* }
$$

Go IWASHITA

\begin{abstract}
In schools, sick leave might to be a significant index of productivity. Elementary schools are thought to be amplifiers for infections in influenza in communities. In School Health and Safety Act, children are told to stay home in case of an epidemic of influenza. The humidity ratio had been reported to be a critical factor for infection of influenza. However the relationship between the really measured indoor thermal factors and the incidence of influenza is rarely investigated. Then the room temperature and relative humidity were continuously measured in twelve classrooms in a public elementary school in Tokyo. And the period of analysis was set as 3 winter seasons from 2005/2006 to 2007/2008. The average values of the room temperature per every winter season in all classrooms were met the School Environmental Sanitary Standard. On the other hand, the average values of indoor relative humidity in some classrooms were lower than the standard value. The high correlation coefficients were not obtained in the relationship between the average values of indoor thermal factors, i.e., air temperature, relative humidity, and humidity ratio per every winter season in each classroom, and the number of absence on account of flu. Focusing on the period when absence on flue had occurred, the room temperature of two days before the absence had a high correlation with the number of absence on flu.
\end{abstract}

$\begin{array}{ccc}\text { Keywords: Influenza, Elementary schools, Humidity ratio, } & \text { Relative humidity } \\ \text { インフルエンザ， 小学校， 絶対湿度， 相対湿度 }\end{array}$

\section{1. はじめに}

環境の質が在室者のプロダクティビティへ及ぼす影響を算定する 方法の一つとして，1）懄や不在・休息や仕事中の中断時間， 2) 病気欠勤，事故，怪我等に伴う保健医療費，等が挙げられている。 Fisk らは換気量の増加につれオフィスの病気欠勤が減ることを報告 し1），岩下らは欠席調査により冷房機設置前後の小学校の児童病欠 率の比較を行っている ${ }^{2}$ 。 プロダクティビティの指標として模擬夕 スクの単位時間当たりの作業量などを用いた研究だけでなく, 病気 欠席や事故の発生頻度をプロダクティビティの指標として捉える研 究も増えつつある。

対象とする室内環境を学校教室に想定した場合, 怪我などの事故 と同等に重要視されるのは病気であり, 特に冬期に問題となるのは インフルエンザの発生であろう。これまでインフルエンザに罹った 場合, 「解熱後 2 日間は出席停止」（幼児は 3 日）という基準のみが 定められていたが，2014 年 4 月の学校保健安全法改正により，「発
症後 5 日を経過し，かつ解熱した後 2 日（幼児は 3 日）を経過する まで出席停止となること」と変更され，保護者，教育者へインフル エンザ対策の意識の周到が進んでいる。インフルエンザの流行では, 曝露歴が少なく活動性の高い児童が密集して長時間生活する小学校 が感染の増幅器となることが懸念されている，と清水らは述べてい る ${ }^{3}$ 。。彼らが三重県のある小学校で解析したインフルエンザ発症状 況によると, 発生児童の感染源は学級内が $50.0 \sim 66.7 \%$, 学級外 (家 庭を含む）が 33.4〜 50.0\%であったとのことである ${ }^{3}$ 。 ンザ感染は教室環境だけではなく, 家庭, 通学, 通塾等の環境の影 響も大きいが, 本研究では, 学級内感染の可能性が 50.0 66.7\% と いう清水らの結果 3)を前提とし，教室環境とインフルエンザ久席と の関係に着目する。

微生物学者 Harper は低湿度でインフルエンザウイルスの生存率が 高かったと報告し4，またやはり微生物学者である Lowen らは，イ ンフルエンザウイルス感染と温湿度の関係を調査して, 暖房によっ

\footnotetext{
* 東京都市大学工学部建築学科 教授・工博
} Prof., Dept. of Architecture, Tokyo City University, Dr.Eng. 
て低下した相対湿度および低温の状態でインフルエンザウイルスが 伝染しやすいことを報告している5)。倉渕らはHarperの実験結果を 用いインフルエンザウイルスの生存率には絶対湿度が重要であるこ とを検証している 6)。一方, 蓬田・近藤らは国立感染症研究所感染 症情報センターのインフルエンザ様疾患発生報告（学級欠席者数） を用いて東京都内の学校施設におけるインフルエンザ感染と湿度の 関係について分析を行い，絶対湿度が低くなるほどインフルエンザ 感染者数が多くなることを報告している7)。庄司らも国立感染症研 究所感染症情報センターのデータを用い，絶対湿度とインフルエン ザ感染との関係を調查しインフルエンザの流行予測を行っている 8)。これら公表されている国立感染症研究所感染症情報センターの データは週単位のデータであるため，比較に用いられる気象データ の湿度は週平均湿度である。また, 公表データに基づく上記の研究 は休校，学年閉鎖，学級閉鎖があった場合に，その施設数や患者数， 久席者数を計上寸るものであり，学級閉鎖等のない通常の授業実施 時における欠席状態の調査とは異なっている。インフルエンザウイ ルスの生存, 活性という点から絶対湿度を気候の指標とする場合が しばしば見受けられるが，ヒ下側の環境で言えば，冬期は寒気のた め鼻咽喉の粘膜が炎症を起こしやすく病原体の侵入が容易であるた め気温および相対湿度が指標とされている場合もある9)。

筆者らは 2005 年 12 月上旬から 2006 年 3 月上旬まで, 東京都の 2 つの小学校教室（計 25 教室）で出欠席調査及び温湿度測定を行い, 相対湿度が $30 \%$ 以下になることが多く教室内相対湿度の低い教室 ほど久席率が高くなる学校と, 相対湿度が 30\%以下になることが少 なく教室内相対湿度と欠席率の相関が見られない学校が見られたこ とを報告した ${ }^{10)}$ 。この研究においては久席率，湿度とも実測期間で ある 3 ケ月の平均值を基に分析を行っている。

上述したような，週単位や月単位の温湿度データおよび久席デー タを用いて分析した例に比べ，たとえば日単位のような，より細か い時系列単位のデータを用いてインフルエンザによる欠席と温湿度 データとの関連を調查した研究は少ない。また教室内での感染の増 幅度合いを想定すると, 各教室で測定された温湿度データとインフ ルエンザ久席変動との関係を調べることが有用と思われる。そこで 本研究では，まず第一に，東京都のある小学校において冬期 3 年間 にわたり出欠席調査および温湿度測定を行い，インフルエンザによ る久席率と教室内温湿度との関係を考察した。また，前述したよう にインフルエンザの感染源は教室内のみではないと考えられるた め，学級外での外気温湿度条件とインフルエンザ久席との関係につ いても検討することとする。

\section{2. 調查方法}

本研究の実測対象となったのは，東京 23 区内の暖房設備（FF 暖 房）を有し，換気設備を持たない公立 S 小学校であり，実測年度は 表 1 に示すように 2005 年度冬期，2006 年度冬期，2007 年度冬期で ある。換気は主に空開けによって行われていた。

$S$ 小学校は各学年 2 学級の計 12 学級からなる。 $S$ 小学校の 2 階お よび 3 階の平面図を図 1 に示す。

$\mathrm{S}$ 小学校の普通教室において表 1 に示す期間に空気温度，相対湿 度の連続測定を行った。温湿度測定はメモリ一付温湿度計（T\&D 社 $72 \mathrm{U})$ を用い，各教室の黒板上部に設置した。測定間隔は 30 分であ
る。実測対象校では，養護教諭により，毎日，学級ごとの出欠席票 が作成されており，その中の出席停止データのうち，インフルエン ザによる出席停止データを本研究におけるインフルエンザ久席デー タとした。

Table 1 Measured factors and measuring period

\begin{tabular}{|l|l|l|}
\hline Year & measuring period & measured factors \\
\hline 2005 & Dec. $1^{\text {st }} / 2005 \sim$ March $8^{\text {th }} / 2006$ & room temperature, \\
\cline { 1 - 2 } 2006 & Dec. $8^{\text {th }} / 2006 \sim$ March $6^{\text {th }} / 2007$ & $\begin{array}{l}\text { relative humidity } \\
\text { (every } 30 \text { minutes) }\end{array}$ \\
\hline 2007 & Dec. $10^{\text {th }} / 2007 \sim$ Feb. $27^{\text {th }} / 2008$ & \\
\hline
\end{tabular}
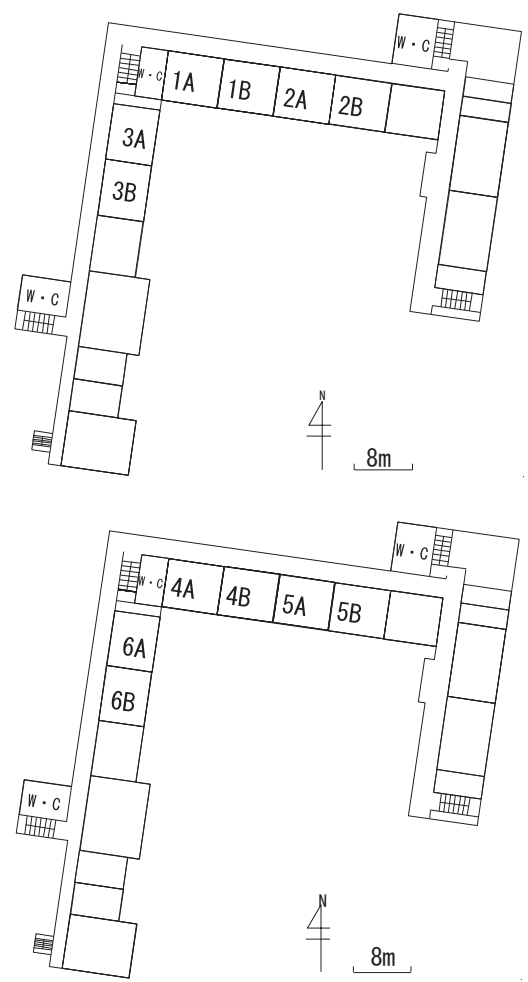

Fig.1 Plan of school S (upper: $2^{\text {nd }}$ floor, lower $3^{\text {rd }}$ floor)

Table 2 Number of pupils and absences on account of illness or flu per each season in each class

\begin{tabular}{|c|c|c|c|c|c|c|c|c|c|}
\hline & \multicolumn{3}{|c|}{2005} & \multicolumn{3}{|c|}{2006} & \multicolumn{3}{|c|}{2007} \\
\hline & no. & \begin{tabular}{|l} 
illnes \\
S
\end{tabular} & flu & no. & $\begin{array}{l}\text { illnes } \\
\mathrm{s}\end{array}$ & flu & no. & \begin{tabular}{|l} 
illnes \\
$\mathrm{s}$
\end{tabular} & flu \\
\hline 1st grade, $A^{*}$ & 37 & 62 & 3 & 31 & 59 & 0 & 30 & 40 & \\
\hline 1st gra & 39 & 62 & 4 & 32 & 28 & 0 & 31 & 37 & \\
\hline $2 \mathrm{nd} \mathrm{C}$ & 27 & 46 & 0 & 38 & 95 & 0 & 29 & 42 & \\
\hline $2 \mathrm{nd} \mathrm{g}$ & 28 & 35 & 17 & 40 & 50 & 0 & 30 & 21 & \\
\hline $3 \mathrm{rd} \mathrm{g}$ & 39 & 57 & 7 & 27 & 29 & 0 & 38 & 56 & 5 \\
\hline $3 \mathrm{rd} \mathrm{g}$ & 39 & 107 & 1 & 26 & 24 & 0 & 38 & 33 & 3 \\
\hline 4th gr & 35 & 52 & 6 & 39 & 43 & 0 & 27 & 25 & \\
\hline 4th $\mathrm{gr}$ & 35 & 37 & 8 & 38 & 80 & 0 & 24 & 17 & \\
\hline 5th grade, $A$ & 37 & 48 & 10 & 33 & 57 & 0 & 38 & 44 & \\
\hline 5 th 9 & 37 & 32 & 6 & 35 & 44 & 0 & 37 & 66 & 5 \\
\hline $\operatorname{sth} c$ & 30 & 59 & 4 & 36 & 40 & 0 & 34 & 56 & \\
\hline the & 29 & 58 & 12 & 37 & 31 & 0 & 35 & 32 & 10 \\
\hline verage & 34.3 & 54.6 & 6.5 & 34.3 & 48.3 & 0 & 32.6 & 39.1 & 6.3 \\
\hline
\end{tabular}

$*$ Class A of 1st grade number: number of pupils in each class illuness: number of absence on account of illness flu: number of absence on account of flu 


\section{3. 実測結果}

\section{1 実測期間平均}

S 小学校の 2005 年度冬期， 2006 年度冬期，2007 年度冬期の実測 期間における各学級の在籍人数, 病欠数およびインフルエンザ久席 数を表 2 に示す。病欠数とは病気を理由に欠席をした生徒数，イン フルエンザ久席数はインフルエンザと医師に判断され出席停止とな った生徒数である。

Table 3 Room temperature, relative humidity and humidity ratio

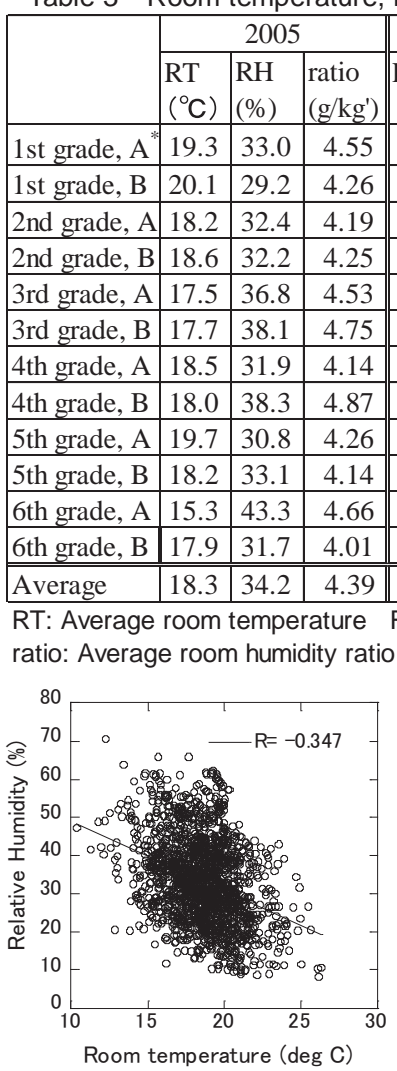

Fig.2 Room temperature and indoor relative humidity

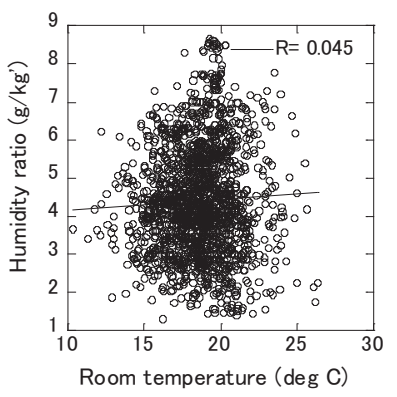

Fig.3 Room temperature and indoor humidity ratio
Table 4 Reported number of incidence of flu in Tokyo during measuring period

\begin{tabular}{|l|r|l|l|r|l|l|l|r|r|}
\hline & \multicolumn{3}{|c|}{2005} & \multicolumn{3}{|c|}{2006} & \multicolumn{3}{|c|}{2007} \\
\cline { 2 - 10 } & start $^{* 4}$ & end $^{* 5}$ & com. $^{* 6}$ & start & end & com. & start & end & com. \\
\hline closing grades $^{* 1}$ & 0 & 0 & 0 & 0 & 109 & 109 & 13 & 41 & 28 \\
\hline closing classes $^{* 2}$ & 1 & 463 & 462 & 0 & 481 & 481 & 97 & 359 & 262 \\
\hline absence $^{* 3}$ & 13 & 10089 & 10076 & 0 & 11540 & 11540 & 1544 & 5530 & 3986 \\
\hline
\end{tabular}

*1 temporary closing grades *2 temporary closing classes

* 3 number of absence on account of flu * 4 at the start of the winter season (A)

${ }^{*} 5$ at the end of the winter season (B) $\quad{ }^{*} 6$ comutative value, (B)-(A)

室温，相対湿度，絶対湿度の平均值を表 3 に示す。なお表 3 のデ 一夕は生徒が在籍していると考えられる午前 8 時半から午後 4 時ま でのデータを用いている。また土日および冬休み期間は除いている。 図 2 に全測定データにおける室温と室相対湿度との関係を図 3 に室 温と絶対湿度との関係を示す。表 3 , 図 2 , 図 3 を見ると, 各学級の 室温は学校環境衛生基準に記載されている $10^{\circ} \mathrm{C}$ 以上 $30^{\circ} \mathrm{C}$ 以下とい う望ましい範囲内に入っていることがわかる。一方，各教室の相対
湿度は学校環境衛生基準の望ましい範囲である $30 \%$ 以上 $80 \%$ 以下 という範囲から低い側に外れているケースがいくつか見られる。

表 2 に示したインフルエンザ久席者数は, 毎日記録されるインフ ルエンザ久席者数の各年度（冬期調查期間）毎の延人数である。表 2 を見ると， 2006 年度冬期のインフルエンザ欠席者数が 0 名となっ ており，他の年度に比へ顕著に少ない数となっている。国立感染症 研究所感染症情報センターのインフルエンザ様疾患発生報告（学級 久席者数）の実測対象期間における東京の久席者数は表 4 に示寸よ うに，2006 年度のインフルエンザ発生数が少ないわけではない。表 4 には本実測研究と同時期の調查期間における東京都のインフルエ ンザ様疾患による学年閉鎖数（temporary closing grades）, 学級閉鎖 数 (temporary closing classes), 欠席者数が示されている。「開始時 (start)」の闌に示されている数は，本実測研究の各年度の開始時に 相当する週の東京都の值を示しており，「終了時(end)」の欄の数は 本実測研究の各年度の終了時に相当する週の值である。また「累積 (com.)」は「終了時」の值から「開始時」の值を引いたものである。 2006 年度のインフルエンザ様疾患発生報告では開始時には報告数 が 0 であったのに対し，2007 年度では開始時に既に多くのインフル エンザ様疾患が報告されていたことがわかるが，本実測研究におけ る各年度の平均インフルエンザ久席数との相関は低い。通学距離が 短く公共交通を通学に用いない公立 S 小学校ではインフルエンザの 流行は, 東京都全体の流行傾向とは異なっていることが推測される。 また，表 3 を見ると 2006 年の絶対湿度が全体的に 2005 年，2007 年 より高くなっていることがわかり，その影響も推察される。

表 3 に示した空気温度, 相対湿度及びこれらから計算によって求 めた絶対湿度と病欠数・インフルエンザ久席者数との関係を図 4〜 図 6 に示す。病欠数は $1 / 10$ の值がプロットされている。また, 図 4 〜図 6 では, 各プロットが表 2 および表 3 中の各学級の值を示して いる $(\mathrm{n}=36)$ 。図 4 の相関係数 $\mathrm{R}$ は 0.19 と低く, 両者に相関関係は見 られない $(\mathrm{p}=0.27)$ 。図 5 に示した各学級教室内の平均相対湿度とイ ンフルエンザ久席者数との関係においても相関係数 Rは-0.332 と高 くはなく，相関関係は危険率 $5 \%$ では有意ではない（ $\mathrm{p}=0.054 ）$ 。ま た，図 6 に示した絶対湿度とインフルエンザ久席者数の関係でも相 関係数 R は-0.334 と高くなく相関も危険率 $5 \%$ では有意ではない $(\mathrm{p}=0.053)$ 。

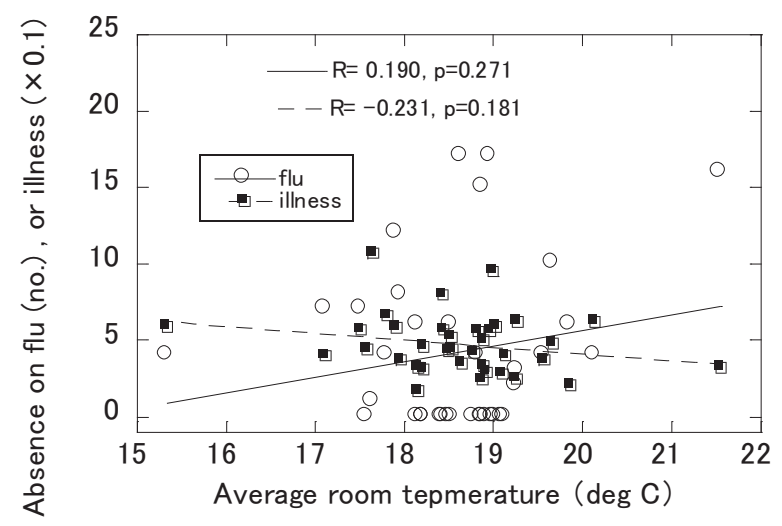

Fig.4 Daily average room temperature as a function of the number of absence of flu or illness per every season in each class 




Fig.5 Daily average room relative humidity as a function of the number of absence of flu or illness per every season in each class

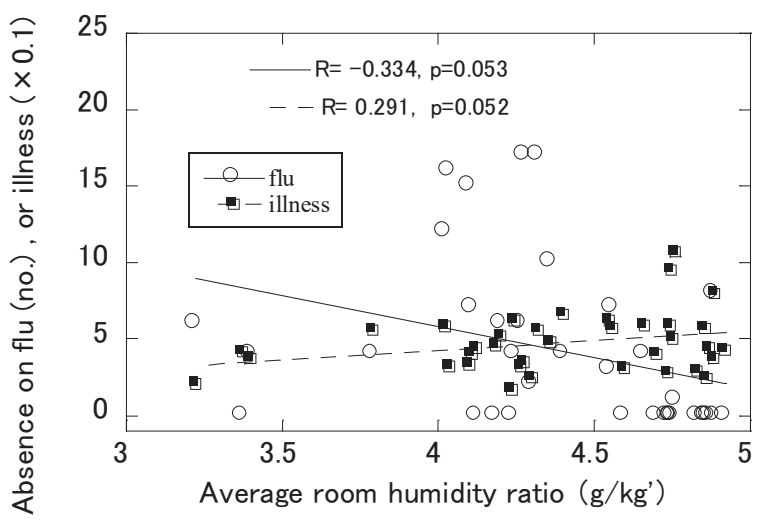

Fig.6 Daily average room humidity ratio as a function of the number of absence of flu or illness per every season in each class

\section{2 経日変化}

インフルエンザ欠席の発生があった学級におけるインフルエンザ 欠席発生日と, インフルエンザ久席人数の一覧を表 5 に示す。表 5 は 2005 年, 2007 年度実測の結果であり，2006 年度はインフルエン ザ欠席が無かったため無い。

表 5 を見ると, ある期間にインフルエンザ欠席が複数学級に同時 発生していることが見受けられるが，必ずしも隣接する学級で相関 が高いわけではない。本研究では学級間の交流頻度や異学年におけ る兄弟姉妹の存在に関するエビデンスを有していないため, インフ ルエンザ久席とこれらとの関係は考慮せず，各学級内の環境を単位 として調查することとする。また，児童の家庭環境や通塾度合い， 週末の過ごし方等の情報も有していないため, 当該調查対象の教室 以外の住環境の状態は一様と仮定する。

表 5 の結果から，インフルエンザ久席を時系列に考察するため, インフルエンザ欠席数の自己相関係数 (Autocorrelation) を求め, 図 7 に示した。自己相関係数とは, 当該日におけるインフルエンザ久席 数と, $\mathrm{n}$ 日前 (後) のインフルエンザ久席数との相関係数であり, 当該日（lag=0）のデータ数は 105 個である。清水らは，インフルエ ンザの潜伏期間を基本的には $1 \sim 2$ 日, 長めに設定して 3 日間と捉え ており ${ }^{3)}$ ，本研究においても，インフルエンザ久席の前後 3 日間を 時系列解析の範囲とした。1 日前のインフルエンザ久席数との相関 係数は図中, lag $=-1$ で表され, 1 日後との相関係数は lag=1 で表さ
れる。当該小学校は土日休日のため, 月曜日の值を対象とした場合, $\mathrm{lag}=-1,-2$ （日）のデータは無く, $\mathrm{lag}=-3$ (日）は前週の金曜日の データとなるが，週末の各児童の過ごす環境は平日に比心゙差が大き いと考えられるため, 週末をはさんだ $\mathrm{lag}=-3$ はデータとして用い ていない。

Table 5 Number of absentees for flu in each class

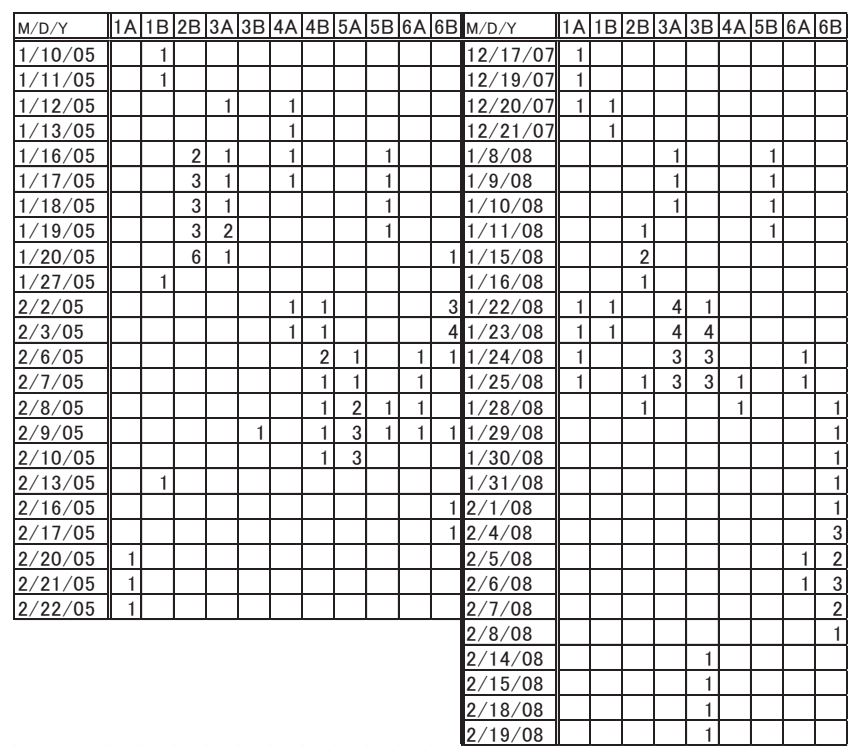

$M / D / Y:$ month/day/year

$1 \mathrm{~A}:$ Class $\mathrm{A}$ of 1 st grade

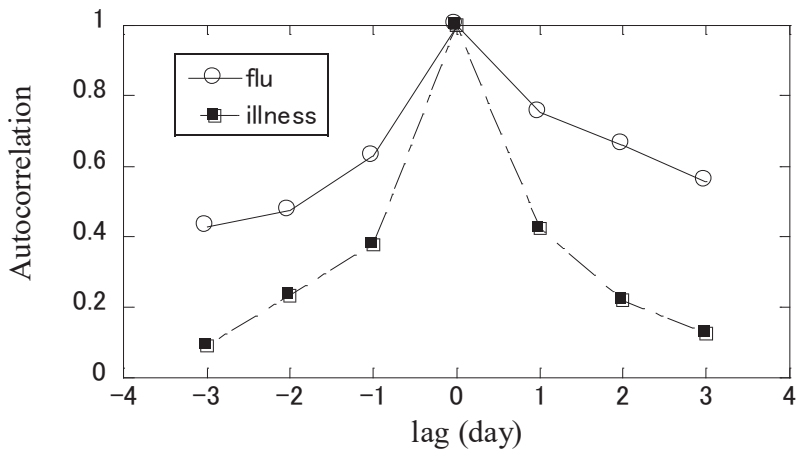

Fig.7 Autocorrelation of absentees for flu and that for illness

図 7 を見ると，インフルエンザ久席数（flu）の 1 日前 $(-1)$ と の自己相関係数は $0.63,1$ 日後との自己相関係数は 0.75 であり, 3 日の範囲では正值の lag の方が相関係数が高い。週頭にインフルエ ンザ久席数の増加がみられ, これが週の中盤まで続くケースが多く, 正值の lag の方が自己相関係数が高いのは，このような状況を表し ていると考えられる。週頭のインフルエンザ久席数の増加を過去に 遡った場合, 週末にかかってしまいデータが得られないため, 負值 の lag の自己相関係数が相対的に低くなったのだと考えられる。清 水らは, インフルエンザ久席初日を発症日とし，その前日を他の児 童への感染可能日としている ${ }^{3)}$ 。週末データの無い本研究では, 週 頭にインフルエンザ久席初日が多いが，その場合，感染可能日の前 日は週末にかかるため，影響を算定できない。インフルエンザ久席 の前日が週末にかからないデータのみで, 感染可能日である前日の 
影響は評価されることになる。図 7 には病欠数(illness)の自己相関係 数も示寸が, 同一の lag において, インフルエンザ久席数の自己相 関係数は病欠数に比べ顕著に高い。

表 5 に示したインフルエンザ久席発生の期間のデータを用い，各 日における各教室の温湿度データとインフルエンザ久席者数との対 データ $(\mathrm{n}=105)$ を基に回帰分析を行った。図 8 に室温の階級別に分類 したインフルエンザ久席率 (Proportion of flu) と室温階級との関係を 示す。横軸の室温階級は $3^{\circ} \mathrm{C}$ 間隔で設けられており, 例えば最初の プロットである $12.5^{\circ} \mathrm{C}$ の階級は $11^{\circ} \mathrm{C}$ 超 $14^{\circ} \mathrm{C}$ 以下の室温範囲を示し ている。表 5 に示されたインフルエンザ久席の各データが発生した 日の発生教室の日平均室温に着目し，日平均室温階級に発生有無デ 一タ $a_{i}(0$ か 1) を配分した。ここで日平均室温とは午前 8 時半から 午後 4 時までの室温の平均値である。各室温階級に配分されたイン フルエンザ欠席発生有無データ $a_{i}$ は表 5 のようにそれぞれが 1 ～6 名の欠席者数 $S_{i}$ を有しており, 式(1)のように当該階級に配分され た $S_{i}$ の総和を当該階級に配分された $a_{i}$ の総和で除した值がインフル エンザ久席率 $P i$ となる。表 5 のインフルエンザ久席発生期間を対象 としているため, 最低值は 1 であり, 久席者数が多い階級ほど，イ ンフルエンザ久席発生率は高くなっている。

$$
P_{i}=\frac{\sum S_{i}}{\sum a_{i}}
$$

ここで, $P i$ : 階級 $\mathrm{i}$ のインフルエンザ久席率

$a_{i}$ : 階級 $\mathrm{i}$ に配分されたインフルエンザ欠席有無データ（0 か 1)

$S_{i}$ : インフルエンザ久席有無データ $a_{i}$ の欠席人数

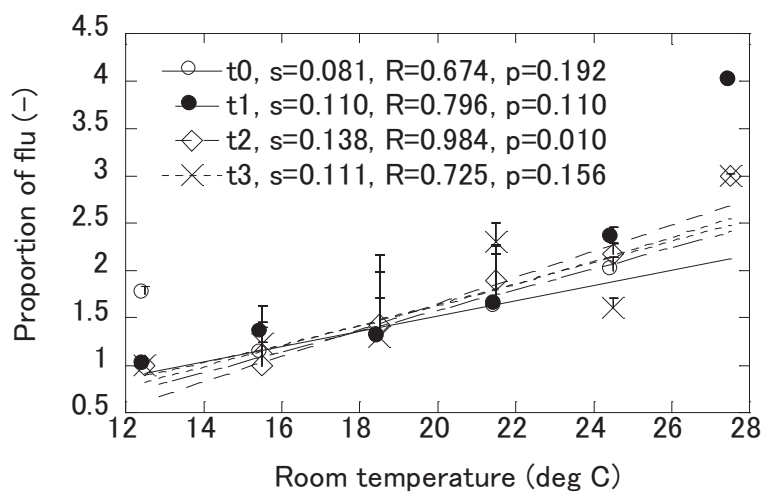

Fig.8 Daily average room temperature as a function of the proportion of flu in each category class

「t0」の凡例は，インフルエンザ久席のあった当日の当該教室内 平均空気温度との相関を表しており,「t1」はインフルエンザ久席の あった前日の平均室温との相関を，「t $2 」 は 2$ 日前の平均室温との, 「t3」は 3 日前の平均室温との相関を表している。月曜日にインフ ルエンザ久席が発生した場合，1 日前となる $\mathrm{t} 1$ は日曜日となるため, このように週末に lag がかかる場合は，図 7 と同様にデータは得ら れない。月曜日にインフルエンザ久席が発生した場合の三日前 (t3) は前週の金曜日となるため, データは存在するが，前述のように週 末をはさんだ解析は行わないこととした。なお，教室の日平均室温 は前述したとおり午前 8 時半から午後 4 時までのデー夕を用いて算 出している。室温とインフルエンザ久席率との因果関係を把握する
理論的なモデルは不明なため，ここでは第一段階として回帰は線形 回帰によって行った。相関係数 R 及び図中に示した回帰直線の算定 には，各階級に含まれるデータ数による重み付けを行っている。 to における各階級に含まれるデータ数の $1 / 50$ が図中プロットのエラ 一バーとして表示されている。図中, s は一次回帰式の傾きを示す。 図 8 ではインフルエンザ久席の二日前の室温（t2）の夕相関係数の $\mathrm{p}$ 值が $5 \%$ を下回っており相関係数が有意であり，また，インフルエ ンザ久席の生じた当日の室温（t0）との相関係数よりも高くなって いる。

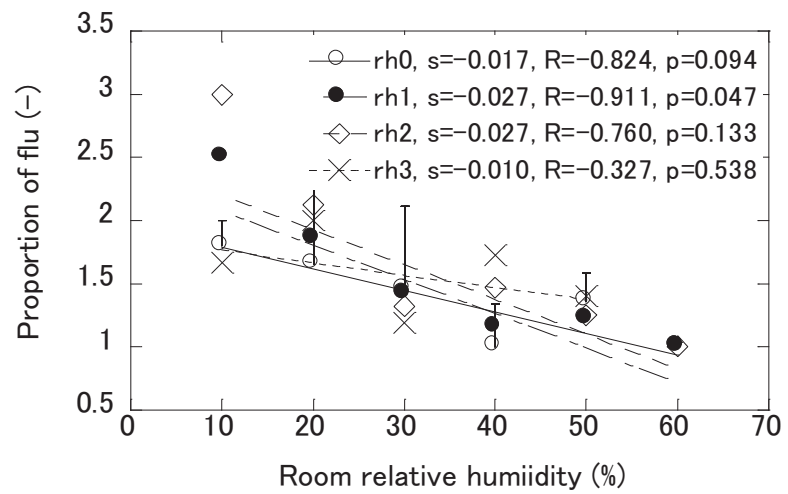

Fig.9 Daily average room relative humidity as a function of the proportion of flu in each category class

図 9 に教室内の相対湿度階級別に分類したインフルエンザ久席率 と相対湿度階級との関係を示す。横軸の相対湿度階級は $10 \%$ 間隔で 設けられており, 例えば 30\%の階級は 25\%超 35\%以下の相対湿度範囲 を示している。「rho」の凡例は，インフルエンザ久席のあった当日 の当該教室内平均相対湿度との相関を表しており，「rh3」はインフ ルエンザ久席のあった 3 日前の平均相対湿度との相関を表している。 相関係数 R 及び図中に示した回帰直線の算定には，各階級に含まれ るデータ数による重み付けを行っている。

図 9 では rh1 のみ $\mathrm{p}$ 值が $5 \%$ を下回っており，相関係数が最も高 くなっている。

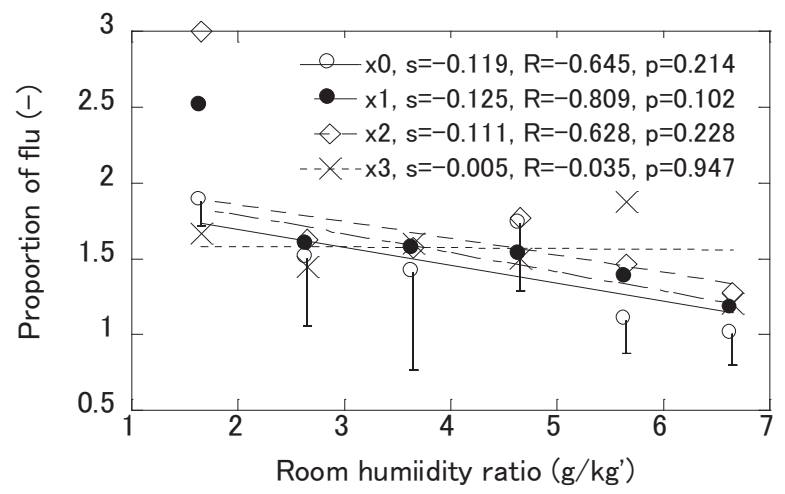

Fig.10 Daily average room humidity ratio as a function of the proportion of flu in each category class

図 10 に教室内の絶対湿度階級別に分類したインフルエンザ欠席 率と絶対湿度階級との関係を示す。横軸の絶対湿度階級は $1 \mathrm{~g} / \mathrm{kg}$ ' 間隔で設けられており, 回帰は線形回帰を行っている。「x0」の凡例 は，インフルエンザ久席のあった当日の当該教室内平均絶対湿度と の相関を表しており,「x3」はインフルエンザ久席のあった 3 日前の 
平均絶対湿度との相関を表している。図 10 では x0〜 x3 のどれにつ いても相関は $5 \%$ の危険率では有意ではない。相関係数 $\mathrm{R}$ も図 8 , 図 9 に比べ低くなっているが，その中でインフルエンザ久席率との相 関が最も高いのは 1 日前の絶対湿度 (x1) であることがわかる。

\section{4. 考察}

小学校におけるインフルエンザの感染源は学級内と同等に学級外 も考えられるため, 気象データから得られる東京の温湿度要素之本 実測で得られたインフルエンザ久席率との関係を求めることにした。 気象データは気象庁監修の「地上気象観測時日別」に基づく「気象 データベース・地上観測」 ${ }^{11}$ の 2005〜2007 年度の東京における日別 データを用いた。図 11 に測定期間における外気温と外気相対湿度と の関係を, 図 12 に外気温と外気絶対湿度との関係を示寸。外気温は 学校環境衛生基準に記載されている $10^{\circ} \mathrm{C}$ 以上 $30^{\circ} \mathrm{C}$ 以下という望ま しい範囲内から低い側に大きく外れ，外気相対湿度は学校環境衛生 基準の望ましい範囲である $30 \%$ 以上 $80 \%$ 以下という範囲に多くの データが入っている。これは図 2 の教室内条件と逆の結果である。

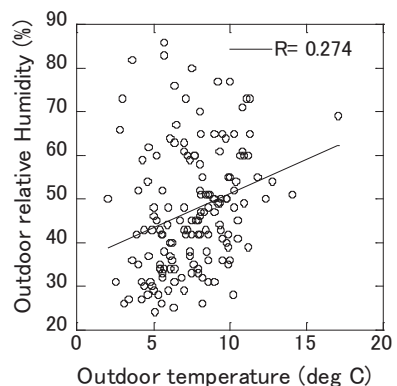

Outdoor temperature (deg C)

Fig.11 Outdoor temperature and the outdoor relative humidity



Fig.13 Daily average outdoor temperature as a function of the proportion of flu in each category class

図 8〜図 10 に用いた各日におけるインフルエンザ欠席数データ $(n=105)$ を当該日の日平均外気温度, 日平均外気相対湿度及びこれら から算定される日平均絶対湿度とマッチングさせた。図 13 に外気温 の階級別に分類したインフルエンザ久席率を示寸。「ot0」の凡例は, インフルエンザ久席のあった当日の日平均外気温との相関を表して おり，「ot1」はインフルエンザ久席のあった前日の日平均外気温と の相関を，「ot2」は 2 日前の日平均外気温との,「ot3」は 3 日前の 日平均外気温との相関を表している ot1〜ot3 の lag が週末にかかる 場合，データは得られない。相関係数 R及び図中に示した回帰直線 の算定には，各階級に含まれるデータ数による重み付けを行ってお
り, 回帰式は線形回帰を用い, 図中， $\mathrm{s}$ は一次回帰式の傾きを示し ている。

図 13 では ot0 のみ相関が有意 $(\mathrm{p}<0.05)$ である。図 8 の室温との 相関では相関係数の值が正であり, 室温の上昇とともにインフルエ ンザ欠席率が上昇する傾向があったが, 図 13 では相関係数が有意で あった ot0の相関係数值は負であり，外気温の低下とともに欠席率 が上昇している。図 13 では図 8 に比べ温度が低く, 基準の $10^{\circ} \mathrm{C}$ 下回っているため，室温上昇による相対湿度の低下という図 8 にお ける温度の間接的な影響ではなく，寒さによる直接的な寄与がイン フルエンザ久席率上昇に表れていると考えられる。外気温の中で当 日の外気温（ot0）のみ相関係数が有意であったのは，インフルエン ザ久席の発生が直近の寒さの影響を大きく受けていることを示すと 思われる。また図 13 における ot0 の回帰直線の傾きは, 図 8 で最も 相関係数の高かった $\mathrm{t} 2$ の傾きより小さい。

図 14 に気象データで得られた東京の外気相対湿度階級別に分類 したインフルエンザ久席率と外気相対湿度階級との関係を示す。 「orh0」の凡例は, 当日の日平均外気相対湿度との相関を表してお り,「orh3」は 3 日前の日平均外気相対湿度との相関を表している。 図 14 では外気相対湿度 $60 \%$ 以下では相対湿度の低下とともにイン フルエンザ久席が上昇する傾向が見られるが，orh0〜orh3 のどの相 関係数も相関は有意ではない $(\mathrm{p}>0.05)$ 。

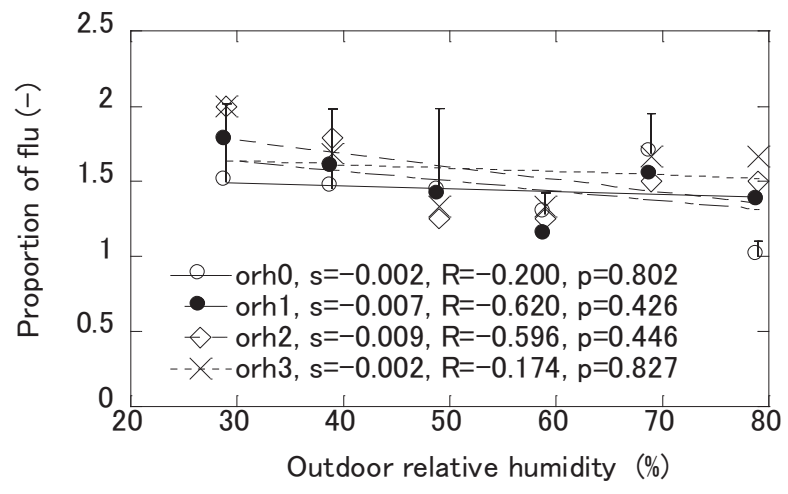

Fig.14 Daily average outdoor relative humidity as a function of the proportion of flu in each category class

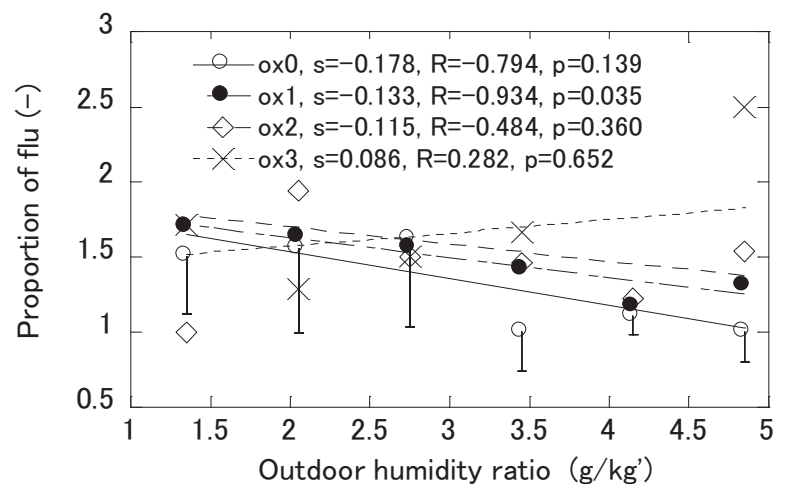

Fig.15 Daily average outdoor humidity ratio as a function of the proportion of flu in each category class

図 15 に気象データから得られた東京の外気絶対湿度階級別に分 類したインフルエンザ久席率と外気絶対湿度階級との関係を示す。 図 15 では 1 日前の屋外絶対湿度（ox1）のみ相関が有意であり $(p<0.05)$, 外気絶対湿度が低いときほどインフルエンザ久席率が高 
くなっている。絶対湿度がほぼ同範囲に散布していた図 10 の室内絶 対湿度とインフルエンザ久席率との関係において, 最も相関係数の 高かったx1の回帰式の傾きと図 15 の ox1 の傾きを比べると, 傾き $\mathrm{s}$ は同等の值となっている。

ここまで, 室内因子, 屋外因子のそれぞれがインフルエンザ久席 率に及ぼす影響を個々に調査してきたが，これらの因子は独立して 制御されたわけではなく, 複数の因子が同時に変動している。そこ で，表 5 に示したデータを用いて重回帰分析を行った。目的変数は インフルエンザ久席者数, 説明変数は図 8〜図 10, 図 13〜図 15 に おいて $\mathrm{p}$ 值が $5 \%$ 未満であった， 1 日前の室内相対湿度 (rh1)， 2 日 前の室温 ( $\mathrm{t} 2$ ), 当日の屋外気温 (ot0), 1 日前の屋外絶対湿度 (ox1) である。各説明変数の統計值を表 6 に示すが，重回帰式の $\mathrm{p}$ 值は 0.0047 であった。表 6 中の因子の内, p 值が $5 \%$ 未満を満たすのは 2 日前の室温 $\mathrm{t} 2$ のみであり, 偏相関係数 (partial correlation coefficient) が 0.29 と最も高い。標準偏回帰係数(standard partial regression coefficient)の絶対值を見ると, t2 が最も大きく, rh1, ot 0 と続くが, ox1 は小さく p 值も大きい。

清水らは, 彼らの研究において, インフルエンザ久席初日あるい は早退日を発症日とし，その前日を他の児童への感染可能日とした 3)。本研究においてもインフルエンザ欠席の 1～2 日前の気候因子の 標準偏回帰係数が高く，インフルエンザ発症日と仮定したインフル エンザ久席初日の 1 ～2 日前を感染可能日と想定することは妥当と 考えられる。しかし, 感受性の差異によりインフルエンザ一次感染 児童が発症せずインフルエンザ欠席に至らなかったとしても，その 児童が感染可能状態になることは考えられ，この場合，インフルエ ンザ久席初日の 1 2 日前を感染可能日とすることはできず, 感染可 能日を見落とすこととなる。

Table 6 Regression/correlation coefficient for each variables

\begin{tabular}{|l|r|r|r|r|r|}
\hline variable & \multicolumn{1}{l|l}{ rh1 } & \multicolumn{1}{l|}{ t2 } & \multicolumn{1}{l|}{ ot0 } & lox1 & $\begin{array}{l}\text { constant } \\
\text { term }\end{array}$ \\
\hline partial regression coefficient & -0.021 & 0.114 & -0.103 & 0.088 & 0.327 \\
\hline standard error & 0.019 & 0.048 & 0.082 & 0.224 & 1.109 \\
\hline standard partial regression coefficient & -0.199 & 0.300 & -0.190 & 0.080 & \\
\hline p-value & 0.279 & 0.021 & 0.211 & 0.695 & 0.769 \\
\hline partial correlation coefficient & -0.139 & 0.290 & -0.160 & 0.050 & \\
\hline
\end{tabular}

従来の研究では絶対湿度がインフルエンザ発生に有意な影響を及 ぼすという報告が多かったが，本研究では湿度因子の内，1 日前の 室内相対湿度および 1 日前の屋外絶対湿度の夕相関係数の $\mathrm{p}$ 值が $5 \%$ 未満であった。これも上述のように,インフルエンザ久席の前日 が感染可能日であるという仮定に合致した結果となっている。

\section{5. まとめ}

東京 23 区内公立 $\mathrm{S}$ 小学校の 12 普通教室 (12 学級) において, 2005 年度冬期, 2006 年度冬期, 2007 年度冬期に空気温度, 相対湿度の連 続測定及びインフルエンザ久席調査を行った。その結果, 以下の知 見が得られた。

1) 各学級の各冬期期間の平均室温は学校環境衛生基準に記載されて いる $10^{\circ} \mathrm{C}$ 以上 $30^{\circ} \mathrm{C}$ 以下という望ましい範囲内に入っていた。一方,
各教室の平均相対湿度は学校環境衛生基準の望ましい範囲である $30 \%$ 以上 $80 \%$ 以下という範囲から低い側に外れている学級がいく つか見られた。

2) 各学級の各冬期期間のインフルエンザ欠席数と当該学級の当該期 間の平均温湿度との関係を求めたところ, 高い相関係数は得られな かった。

3) インフルエンザ久席の発生した学級の発生した期間のみのデータ を用い，室内温湿度とインフルエンザ久席率との関係を求めた。イ ンフルエンザ久席発生率との相関係数の $\mathrm{p}$ 值が $5 \%$ 未満であったの はインフルエンザ久席 1 日前の室内相対湿度，2 日前の室温，当日 の屋外気温, 1 日前の屋外絶対湿度であった。

4）目的変数をインフルエンザ欠席数とし, 説明変数をインフルエン ザ久席 1 日前の室内相対湿度，2 日前の室温，当日の屋外気温，お よび 1 日前の屋外絶対湿度とする重回帰分析を行った結果，説明変 数の $\mathrm{p}$ 值が $5 \%$ 未満であったのは 2 日前の室温のみであった。

\section{謝辞}

実測にご協力頂きました東京都公立 $\mathrm{S}$ 小学校の関係各位に謝意を 表します。本実測研究の実施には，当時，東京都市大学建築学科岩 下研究室に在籍していた大学院生，卒論生の諸氏に多くの協力を得 ました。

\section{参考文献}

1) W.J. Fisk, , O. Seppänen, D. Faulkner, J. Huang, : Cost Benefit Analysis of Ventilation Control Strategies in an Office Building, Proc. Of Healthy Buildings 2003, Vol.3, pp.361-366, 2003.12

2）岩下剛, 古賀隆文: 冷房導入後の小学校普通教室における夏季の温熱・空 気環境の実態に関する研究，日本建築学会環境系論文集，第 74 巻, 第 641 号, pp.877-882，2009.7

3) 清水宣明, 片岡えりか, 西村秀一, 脇坂浩 : ある小学校における A (H1N1) pdm09 パンデミックインフルエンザの感染伝播動態の解析, 環境感染誌, Vol.27, No.2, pp.96-104, 2012

4) G.J. Harper : Airborne Micro-organisms: Survival Tests with Four Viruses, J. Hyg., Camb. , 59, pp.479-486, 1961

5) A.C. Lowen, S. Mubareka, J. Steel, P. Palese: Influenza Virus Transmission Is Dependent on Relative Humidity and Temperature, PLoS Parhog, 3, pp.1470-1476, 2007

6）倉㴊隆，小笠原岳，熊谷一清，浅利雄太郎：インフルエンザの感染に影響 するインフルエンザウイルス生存率と絶対湿度の関係について, 空気調 和・衛生工学会大会学術講演論文集, pp.1339-1342, 2009.9

7) 蓬田央, 岩瀬友紀, 近藤靖史, 藤原孝行 : 都立高校教室における室内空気 環境の実測と CFD 解析による換気・空調方式の検討，日本建築学会技術報 告集，第 17 巻，第 36 号，pp.583-587，2011.6

8) 庄司眞 : 季節とインフルエンザの流行, J. Natl. Inst. Public Health, 48(4), pp.282-290, 1999

9) 薩田清明, 乗木秀夫, 坂井富士子, 薮内清 : インフルエンザ流行の時間差 に関する研究一平均気温,平均相対湿度を中心として一, 感染症学雑誌, 第 59 巻第 4 号, pp.355-365, 1985

10) 岩下剛，横山雄樹，仲川純子，阿部正太郎：暖房期間における小学校普 通教室の空気環境及び久席率に関する調查研究 その 1 その 3 , 日本建築 学会大会学術講演梗概集, 環境工学, D-2, pp.63-68, 2006

11）（財）気象業務支援センター監修: 気象データベース地上観測，ウエザー トーイ, 2010 


\title{
TIME SERIES ANALYSIS ON THE INCIDENCE OF INFLUENZA IN ELEMENTARY SCHOOLS DURING WINTER SEASON USING TEMPERATURE AND HUMIDITY
}

Study on the relationship between indoor air environment and the incidence of influenza in schools

\section{Go IWASHITA*}

\author{
* Prof., Dept. of Architecture, Tokyo City University, Dr.Eng.
}

\begin{abstract}
A deteriorated indoor climate is commonly related to increases in sick building syndrome symptoms, respiratory illnesses, sick leave, reduced comfort and losses in productivity. In schools, sick leave might to be a significant index of productivity. Elementary schools are thought to be amplifiers for infections in influenza in communities. In School Health and Safety Act, children are told to stay home in case of an epidemic of influenza. Therefore the indoor air environment should be controlled for avoiding an epidemic of influenza. The humidity ratio had been reported to be a critical factor for infection of influenza. However the relationship between the really measured indoor thermal factors and the incidence of influenza is rarely investigated. Then the room temperature and relative humidity are continuously measured in twelve classrooms in a public elementary school in Tokyo. And the period of analysis was set as 3 winter seasons from 2005/2006 to 2007/2008.

The average values of the room temperature per every winter season in all classrooms were met the School Environmental Sanitary Standard. On the other hand, the average values of indoor relative humidity were not met the standard in some classrooms and lower than the standard value.

The high correlation coefficients were not obtained in the relationship between the average values of indoor thermal factors, i.e., air temperature, relative humidity, and humidity ratio per every winter season in each classroom, and the number of absence on account of flu. Although the tendency was found that the lower the humidity, the greater the number of absence on account of flu, the correlation coefficient was low and not significant.

Focusing on the indoor climatic data when the absence of flu was occurred, the highest correlation coefficient was observed at 0.984 in the relationship between the daily average indoor temperature of two days before the absence and the probability of flu. The second highest correlation coefficient was observed in the relationship between the daily average indoor room relative humidity of one day before the absence and the probability of flu.

The significant high correlation was seen in the relationship between the probability of flu and the daily average outdoor air temperature of the absence day obtained from the meteorological data. The significant high correlation was also found in the relationship between the probability of flu and the daily average outdoor humidity ratio of one day before the absence.

A multiple regression analysis was conducted with the probability of flu as a objective variable. The explanatory variables were indoor and outdoor climatic factors. As a result of the analysis, the room temperature of two days before the absence was merely a significant factor ( $<<0.05)$. A time-series analysis for indoor/outdoor climate especially a few days before the absence could be useful for understanding the infection of flu.
\end{abstract}

